респондент «сообщает, интерпретирует и объясняет любую новость правдиво, даже если точка зрения автора не совпадает с издателем» $[11$, р. 42]. Шеф Берлинского бюро «Chicago Daily Tribune» Сигрид Шульц утверждала, что её непосредственный начальник, Роберт Маккормик, никогда не вмешивался в содержательную часть её репортажей из Германии. Таким образом, утверждения Шульц и Моурер о личностном подходе в освещении событий относятся и к истории «Пивного путча».

Анализ реакции прессы США на «Пивной путч» показывается, что американские газеты в первые же дни развития событий взяли их под своё пристальное наблюдение. Причём тенденции, характерные для центральной прессы (освещение международных событий, стремление к аналитике и прогнозам), свойственны также и небольшим местным периодическим изданиям. Информационное обеспечение «Пивного путча» показывает, что уже в 1923 г. пресса США существенно разошлась в оценках по поводу самого важного вопроса: поддержать мятежников или осудить их. Позиция, занятая влиятельной «Chicago Daily Tribune» - критика правительства Германии, поиск оправданий для Людендорфа, большая боязнь коммунистического переворота, чем ультраправого, - заложит информационную базу для будущего оправдания политики «умиротворения агрессоров» [21, с. 210].

\section{Список литературы:}

1. Буранок С.О. Аншлюс, Мюнхен, Польша... Пресса США и угроза войны в 1938-1939 годов // Россия XXI. 2014. № 5. С. 142-159.
2. Буранок С.О. Героизация битвы за Мидуэй в прессе США // Известия Тульского государственного университета. Гуманитарные науки. 2012. № 1-1. C. 334-339.

3. Буранок С.О. Образ победы над Германией в англоязычной прессе // Вестник Российского гуманитарного научного фонда. 2015. № 1 (78). С. 37-49.

4. Gordon H.J. Hitler and the Beer Hall Putsch. Princeton, 1972.

5. Kershaw I. Hitler: 1889-1936: Hubris. New York, 1999.

6. Literary Digest, 24 November 1923.

7. Springfield Union. 24 November 1923.

8. Baltimore Sun. 24 November 1923.

9. Tuscaloosa News. 20 February 1933.

10. Edwards, J. The Foreign Policy of Col. McCormick's Tribune, 1929-1941.

11. Gary A, Klein. The American Press and the Rise of Hitler, 1923-1933. London. 1997.

12. New York Times. 1923. November 10.

13. Chicago Daily News. 1923. November 10.

14. Chicago Daily Tribune. 1923. November 10.

15. Warsaw Daily Times. 1923. November 9.

16. Toledo Blade. 1923. November 9.

17. Toledo News-Bee. 1923. November 9.

18. Spokane Daily Chronicle. 1923. November 9.

19. Southeast Missourian. 1923. November 9.

20. Painesville Telegraph. 1923. November 9.

21. Буранок С.О. Трагедия в Перл-Харборе и американская пресса // Новая и новейшая история. 2010. № 5. C. 210-220.

\title{
«BEER HALL PUTSCH» IN THE US PRESS ASSESSMENT
}

(C) 2018

Tulusakova Margarita Igorevna, postgraduate student of World History,

Law and Methods of Teaching Department

Samara State University of Social Sciences and Education (Samara, Russian Federation)

Abstract. The paper studies the problem of the American press reaction to an attempted coup in Germany in 1923. The reasons for the «Beer Hall Putsch» from the point of view of the press were studied. The author shows the process of information accumulation about the putsch, the role and attitude of various representatives of the US press to it, and the international reaction to the Nazism. The role of Hitler in the coup attempt is analyzed. The author proves that there was direct influence of large American newspapers chief editors' opinions on the information about the coup in Germany. The analysis of the US press reaction to the «Beer Hall Putsch» shows that American newspapers during the first days of the events observed these events closely. Moreover, the trends typical for the central press (coverage of international events, desire for analytics and forecasts) were also characteristic of small local periodicals. The Beer Putsch information support shows that in 1923 the US press was clearly divided in assessments about the most important issue: to support the rebels or to condemn them. The paper shows how the image of the «Beer Hall Putsch» influenced the policy of aggressors' pacification in the future.

Keywords: the US press; public opinion; Germany; Weimar Republic; «Beer Hall Putsch»; Ludendorff; Hitler; International journalism; Versailles Treaty; appeasement of aggressors; International relations in Europe.

УДК 94

Статья поступила в редакцию 05.01.2018

\section{ТЕРРИТОРИИ ПЛЕМЁН ФЕДЕРАЛЬНОГО УПРАВЛЕНИЯ: БРИТАНСКОЕ КОЛОНИАЛЬНОЕ НАСЛЕДИЕ В ПОСТКОЛОНИАЛЬНУЮ ЭПОХУ}

(C) 2018

Целера Олег Сергеевич, магистрант кафедры всеобщей истории, права и методики обучения Самарский государственный сочиально-педагогический университет (2. Самара, Российская Федераџия)

Аннотация. В представленной статье анализируется роль управленческого опыта Британской империи на Северо-западной границе Британской Индии в XIX - первой половине XX вв. в выборе политического курса Пакистана в отношении Территории племен федерального управления во второй половине XX - начале XXI вв. При этом особое внимание обращается на британские колониальные практики, сохранившие свое 
значение в постколониальную эпоху в зоне племен. Внимание уделено и роли колониального опыта в урегулировании асимметричного конфликта с участием США на территории Афганистана - обращается внимание на особенности взаимодействия Вашингтона и Исламабада в зоне племен. В заключении статьи приводятся выводы о перспективах колониального знания в администрировании Территории племен федерального управления в постколониальную эпоху с учетом и в свете исторического опыта британской колониальной администрации на Северо-западной границе Британской Индии в эпоху империй. Также в статье раскрываются вопросы о влиянии постколониальных практик на историю современного Пакистана и на выбор его пути реформирования ТПФУ (Территорий племен федерального управления), а также о роли других региональных игроков в деле реформирования ТПФУ.

Ключевые слова: территория племен федерального управления; зона племен; Пакистан; Великобритания; Британская империя; Британская Индия; США; Афганистан; Пешавар; пуштуны; Пуштунвали; проект реформы ТПФУ; Миан Мухаммад Наваз Шариф; политические агенты; конституция Пакистана; судебная система ТПФУ; FАТА.

Пакистан всегда был малоизученной темой в отечественной истории. Его чаще всего рассматривали в контексте Пешавара - региона, на территории которого готовились боевики, против которых Советский Союз сражался в годы афганской войны.

Представление о Пешаваре распространялось на весь Пакистан, который почти полвека считался недружественной нам страной, вступившей сначала в CEATO (Организация договора Юго-Восточной Азии, или Манильский пакт, военно-политический блок стран Азиатско-Тихоокеанского региона, существовавший в 1955-1977 гг.), а затем в СЕНТО (Организация центрального договора, в 1955-1958 гг. также часто использовалось название Багдадский пакт). СССР предпочитал дружить с Индией, пытаясь таким образом сдержать Китай. [1, с. 26-27].

После объявления в 1947 г. независимости правительству Пакистана предстояло объединить различные этнические и религиозные группы населения. В этом Пакистану отчасти помогла Великобритания [2]. В акте 1947 г., который расширил акт 1935 г. [3], были указаны необходимые поправки для работы правительств после получения независимости и выработки постоянной конституции. На время главой страны стал генерал-губернатор, появился пост премьер-министра [4].

В 1955 г. Учредительное собрание приняло решение о создании единой провинции Западный Пакистан [5], а затем приняло Конституцию, окончательный вариант которой был утвержден в 1973 г. Coгласно ей, Пакистан становился федерацией, был реализован принцип разделения властей (президент, исполнительная власть - у премьер-министра, законодательная власть - у парламента, судебная власть выделена отдельно) [6].

В 1979 г. обстановка на Севере, которая и так была неспокойной, обострилась. Чтобы кратко охарактеризовать беспокойный характер этого края, достаточно вспомнить строительство железной дороги, затеянное англичанами в 1920-е гг., для соединения Британской Индии с Европой через Афганистан, Иран и Турцию. Она обрывается на границе горской автономии Северо-западной пограничной провинции Пакистана, в Хайберском ущелье, где начинаются племенные территории [7]. Ввод ограниченного контингента СССР в Афганистан вынудил огромное количество людей пересечь границу с Пакистаном, что усугубило ситуацию на территориях с племенным управлением. После событий, связанных с войной в Афганистане в 1980-е гг., эти территории начали в значительной мере контролироваться движением «Талибан» [8].
На сегодняшний момент Хайберское ущелье - это то место, где заканчиваются полномочия полиции и судов Пакистана. Власть принадлежит местным племенам, как и во времена Британской империи, и этому способствует несколько факторов.

Полуавтономные племенные земли состоят из семи политических агентств (понятие «политическое агентство» появилось примерно шестьдесят лет назад, для более удобного обозначения отношений между племенами и центральной властью). Это Баджаур, Куррам, Хайбер, Мохманд, Северный Вазиристан, Южный, Оракзай. Существует также шесть небольших зон, известные как пограничные районы между племенными землями и Северо-западной пограничной провинцией [9].

О пуштунах, в основном населяющих эти земли, европейцы услышали в XIX в., когда племена смогли нанести несколько поражений британскому колониальному корпусу. Главной проблемой стали горцы, расположившиеся между Афганистаном и Британской Индией. Их не признавали ни первый, ни вторая, считалось, что это разбойники [10]. Но после кровопролитных конфликтов пришло осознание, что необходимо договариваться.

В конце XIX в. Великобритания создала особую зону, где племена получили самоуправление [11, p. 49]. Эта идея была сохранена и развита правительством Пакистана. Суровая территория границы племен вдоль границы Афганистана создана британским дипломатом сэром Генри Мортимером Дюрандом как средство разделить и ослабить одиннадцать крупных пуштунских племен и создать буферную зону между Британской и Российской империями. К югу располагается большая провинция Белуджистан, которая также разделена линией Дюранда, не признаваемой Афганистаном и через которую на сегодняшний день переходят талибы [12, p. 231].

Конечно, племенные земли присоединились после 1947 г. к Пакистану, а не к Индии, однако исторически Пакистан фактически не имел твердого контроля над этими землями, как и британцы [12, p. 258].

После получения независимости власти Пакистана решили не менять колониальную систему, сложившуюся с прошлого века, и дали территориям племен особый статус: Территории племен федерального управления [6].

Хотя президент и имеет исполнительную власть над регионом, назначенный губернатор Северозападной пограничной провинции управляет и племенными территориями в том числе [6]. Фактически данные территории автономны, а связь с центральным правительством поддерживается через полити- 
ческих агентов, которые решают вопросы здравоохранения, образования и другие. Сами же племена имеют представителей в национальном собрании Пакистана, но не в собрании Северо-западной пограничной провинции [13, p. 52].

При этом реальная власть находится в зависимости не только от местных вождей, но и от политических агентов, благодаря которым федеральное правительство поддерживает контроль над племенами, в соответствии со старой колониальной практикой. Законы о преступлениях колониальной эпохи уже более века используются в качестве кнута для контроля пограничных племен. Эти положения позволяют политическому агенту налагать коллективное наказание за преступление, совершенное отдельным лицом, и отправлять людей в тюремное заключение без надлежащей судебной процедуры и возможности апелляции [13, p. 68].

Племенами, в соответствии с кодексом Пуштунвали, управляют малики, а высший орган власти джирга, или совет старейшин [14]. Союзы племен дальше дробятся на племена, роды и ветви. Политический агент может в любой момент созвать джиргу и наложить вето на то или иное решение совета [15]. Не удивительно, что в этих землях наблюдается высокий уровень коррупции - в известном смысле тоже наследие колониальной эпохи.

Разные племена имеют разные права, к жителям других провинций Пакистана относятся с большим подозрением. Исторически, со времен Британской империи, центральные власти имели мало влияния на племена, однако после террористических актов 11 сентября 2001 г. правительство США оказало давление на Исламабад, и в зоне племен началась контртеррористическая операция, которая, однако, не увенчалась успехом [16, p. 55].

На сегодняшний момент в зоне племен складывается следующая ситуация. Президенты Пакистана Асиф Али Зардари (2008-2013 гг.) и Миан Мухаммад Наваз Шариф (2013-2017 гг.) заявляли о полном реформировании Территории племен федерального управления (ТПФУ), с целью включения населения в правовое поле Пакистана [17].

Власти учитывают родоплеменную структуру на территориях, как в свое время Британская империя, одновременно рассматривая несколько вариантов решения статуса территорий (сохранение статуса-кво при условии судебной и экономической реформ; полная автономия; отдельная провинция; ликвидация ТПФУ с включением в Хайбер-Пахтунхва) [18].

До настоящего времени действуют Правила регулирования, принятые еще британской колониальной администрацией в 1901 г. [19], что позволяет говорить о преемственности традиций в управлении зоной племен. При этом параллельно начинают действовать правила 2016 г., которые исходят из принципа не коллективной, а индивидуальной ответственности. Однако институт старейшин и система джирги продолжают существовать, и их мнение также будет учитываться [17].

Реформирование зоны племен будет продолжаться до начала 2020-х гг. В 2001-2014 гг. ТПФУ была наводнена боевиками Талибана, так как США вели антитеррористическую компанию в Афганистане, выдавливая противника на территорию соседнего Пакистана. При этом на сегодняшний момент важность этой территории только возрастает, так как Китай планирует включить ее в Китайско-Пакистанский торговый коридор (проект «Новый шелковый путь») [20].
Роль США в вопросе Территорий федерального племенного управления довольно неоднозначна. С одной стороны, они поддерживали идею самоуправления до терактов 11 сентября 2001 года [4], и Пакистан это совершенно устраивало: он планировал заморозить такое положение вещей. Но после терактов под давлением США он был вынужден начать военную операцию, которая оказалась провальной. Помимо снятия ограничений в торговле США оказали большую дипломатическую поддержку (например, на заседании совместной консультативной группы по обороне в 2016 году они горячо приветствовали военные операции в зоне племен Пакистана) [21].

Начиная с 2010 года американцы принимают активнейшее участие в образовательной реформе Территорий племен Федерального управления, так как считают, что проблема терроризма идет из медресе. Пакистанские медресе, если они должным образом управляются, могут обеспечить важную безопасность, как и другие организации гражданского общества. Однако ни пакистанские правительства, ни политики США не могут быть удовлетворены ситуацией в пакистанских медресе по следующим причинам:

- выпускники медресе имеют ограниченную трудоспособность, поскольку у них слабый и устаревший учебный план по сравнению с выпускниками классических школы;

- часто компьютеры и интернет в медресе приравнивают к новым технологиям, однако именно это позволяет ученикам стать уязвимым к интернетагитации террористов;

- несмотря на то, что большинство медресе в Пакистане не связаны ни с одной террористической организацией, они ведут религиозную агитацию своих идей, претендуя на их исключительность;

- хотя доля медресе в общем контексте образования в Пакистане играет небольшую роль, они составляют существенное влияние в Северно-западных пограничных территориях и представляют собой скрытый шанс радикализации населения Пакистана.

Пакистанское правительство должно играть ведущую роль в любых усилиях по реформе медресе, но должно привлечь различные международные организации для проведения образовательных реформ. Реформистские исламские организации сейчас появляются во всем мире, и обмен информацией между такими группами и медресе в Пакистане возможен при содействии иностранных организаций; это может быть в форме совместных семинаров и других способах взаимодействия, которые часто невозможны без донора. Пакистан должен рассчитывать на помощь, помимо США, стран исламского мира. Многие мусульманские страны рассматривают пакистанских священнослужителей с недоверием, так как, по мнению правительств этих стран, они являются инкубатором радикализма. Западные страны, США и другие могут и желают выступить в качестве помощника в деле проведения образовательной реформы.

Объявление президентом Бараком Обама пересмотренной стратегии в отношении Афганистана и Пакистана от 27 марта 2009 года указывает на важность образования для понижения угрозы терроризма в регионе. Ключевой интерес США в зоне ТПФУ - уменьшение угрозы терроризма, так как вследствие слабого влияния правительства Пакистана на эти территории они являются потенциальном источником опасности. При учете того, что военный сценарий развития событий провалился, был избран именно такой путь - через систему образования [22, p. 38]. 
В большей степени этим США пытаются применить практику взаимодействия с племенами ТПФУ через образовательную модель - как самую удобную для контакта с племенами, которые до сих пор сохраняют большую автономию в независимом Пакистане.

Таким образом, на сегодняшний день правительство Пакистана не выработало единого и долгосрочного решения по отношению к пограничным территориям, до сих пор активно используя колониальные практики, доставшиеся стране в наследство от Британской империи, находясь при этом под сильным влиянием США, что отчасти не дает возможности выработать собственную политику по отношению к племенным территориям.

\section{Список литературы:}

1. Лунев С.И. Советско-индийские отношения (1955-1971 гг.): Рождение дружбы // Вестник МГИМО-Университета. 2017. № 2 (53). С. 24-51.

2. India and Pakistan. 18 december 1947. Hansard [El. resource] // India and Pakistan (refugees, relief measures). - https://api.parliament.uk/historic-hansard/ commons/1947/dec/18/india-and-pakistan-refugeesrelief.

3. Indian Independence Act, 1947. 10 \& 11 Geo. 6 . Ch. 30 .

4. Johnson T. Culture, Conflict, and Counterinsurgency. Stanford University Press. 2014. P. 154.

5. Post Independence Problems [El. resource] // Story of Pakistan. - http://storyofpakistan.com/post-independenceproblems.

6. Конституция Исламской Республики Пакистан [Электронный ресурс] // Конституции государств (стран) мира. - http://worldconstitutions.ru/?p=34 .

7. The Editors of Encyclopædia Britannica [El. resource] // Encyclopaedia Britannica. - https://britannica. com/editor/the-editors-of-encyclopdia-britannica/4419.

8. «Pakistan Reopens Khyber Pass To US/NATO» [El. resource] // http://therightperspective.org/2010/10/ 12/pakistan-reopens-khyber-pass-to-usnato.

9. Силаев А.А. Территория племен федерального управления Пакистана - медленная «талибанизация» [Электронный ресурс] // ЦентрАзия. - http://centrasia.ru/ newsA.php?st=1182112860.

\section{FEDERALLY ADMINISTERED TRIBAL AREAS: BRITISH COLONIAL LEGACY IN POSTCOLONIAL AGE}

(C) 2018

Tselera Oleg Sergeevich, master student of World History, Law and Methods of Teaching Department Samara State University of Social Sciences and Education (Samara, Russian Federation)

Abstract. The following paper analyzes the role of administrative experience of the British Empire on Northwest boundary of the British India in 19 - the first half of the $20^{\text {th }}$ centuries in Pakistan political policy choice concerning the federally administered tribal areas in the second half of 20 - the beginning of the $21^{\text {st }}$ centuries. At the same time special attention is paid to the British colonial practices which saved the value during a post-colonial era in the tribes' zone. The author also pays attention to the role of colonial experience in asymmetrical conflict settlement with the USA involvement in Afghanistan territory as well as to features of interaction of Washington and Islamabad in the tribes' zone. The author concludes about perspectives of colonial knowledge in federally administered tribal areas administration during a post-colonial era taking into account historical experience of the British colonial administration on Northwest boundary of British India during the age of empires. The paper also reveals the impact of postcolonial practices on the history of modern Pakistan and on the choice of its way to reform the FATA (Federally Administered Tribal Areas), as well as the role of other regional players in the reform of the FATA.

Keywords: federally administered tribal areas; tribes zone; Pakistan; Great Britain; British Empire; British India; USA; Afghanistan; Peshawar; Pashtuns; Pashtunwali; reform project of the FATA; Mian Muhammad Nawaz Sharif; political agents; constitution of Pakistan; trial of the FATA. 